\title{
EDITORIAL
}

\section{Veredas do discurso entre a gramática e a semiótica social}

Com ênfase na dimensão discursiva e em conexão com o panorama semiótico-social contemporâneo, em que a linguagem se reveste cada vez mais de poder, sobretudo, na combinação verbal-visual, o volume 17(1) de L\&S reúne, em sua primeira edição de 2016, dez estudos voltados para reflexões analíticas em torno de fenômenos linguístico-discursivos que emergem de "contextos de situação" e refletem "contextos de cultura". ${ }^{1}$ São seis artigos assinados por colegas docentes/pesquisadores brasileiros, representantes de diferentes instituições nacionais e uma internacional, bem como quatro artigos que trazem nomes de colegas docentes/pesquisadores dos seguintes países: Argentina, Colômbia, Espanha e Portugal. De acordo com a política editorial de Cadernos de Linguagem e Sociedade, somamse às colaborações duas resenhas elaboradas, respectivamente, por uma mestranda e um doutorando do Brasil.

No espaço deste editorial, atrevo-me a convidar o leitor a navegar, ainda que em um breve parágrafo, pelos rumos do que podemos chamar de um paralelismo semiótico a girar em torno da linguagem em interação. Se compararmos a força do discurso com a da água na correnteza de um rio, podemos ponderar que ambos guardam um ponto de relativa semelhança. A exemplo da água em sua torrencialidade, o discurso como processo costuma correr em várias direções. Mas, diferente de uma corrente de água - que não negocia e tampouco dialoga com pedras e outros obstáculos, uma vez que sempre os contorna de maneira natural -, o discurso, considerado como prática social (e não individual), demanda outra natureza. Resulta que a palavra falada ou escrita, devido à complexidade da linguagem em interação, atrelada sempre à realidade de sua inscrição social, histórica e ideológica, demanda percursos de sentidos sobejamente distantes daqueles pelos quais costumam correr as águas do rio.

\footnotetext{
${ }^{1}$ Os termos "contexto de situação" e "contexto de cultura" são aqui empregados com base nas formulações teóricas propostas por Halliday (2003, p. 4), para quem, entre todos os sistemas semióticos humanos (fisiológico, biológico e social), " a linguagem é a principal fonte de poder".
} 
$\mathrm{Na}$ dimensão discursiva, que faz da língua um contrato social, palavras-pedras costumam surgir no meio do caminho, revestidas de camadas e camadas de sentidos. São aquela que, embora possam evocar a lira do poeta, ao serem proferidas em situações reais tornam-se capazes de provocar ruídos comunicativos, silenciar vozes e até mesmo causar iniquidades sociais, desencadeadas por situações de 'injustiça', 'exclusão' e 'desigualdade'. Sempre incrustadas nas sendas mais profundas da estrutura textual, outras palavras mescladas em expressões, tais como sede de 'legitimidade', abuso de 'poder', bem como de 'autoridade', quando associadas a construções ideológicas, podem também (des)mascarar situações de opressão, cujos sentidos costumam ser identificados, desvelados e, sobretudo, denunciados através de pesquisas na linha dos estudos críticos do discurso, o que envolve a semiótica social.

Para compreender e interpretar o(s) sentido(s) de um dado fenômeno linguísticodiscursivo, os autores que assinam os artigos selecionados atenderam à chamada proposta para compor o presente volume, uma vez que se aproximaram, embora desde diferentes perspectivas teóricas, da temática anunciada como "Veredas do discurso entre a gramática e a semiótica social".

Que a leitura aqui iniciada incentive futuros estudos que conjuguem língua, gramática e discurso, sobretudo, com vistas a uma nova ordem social nos campos político e educacional, bem como no campo midiático, não só no contexto brasileiro, mas também no contexto de outros países.

Denize Elena Garcia da Silva

Editora-chefe de L\&S

Brasília, maio de 2016

\section{REFERÊNCIA BIBLIOGRÁFICA}

Halliday, M.A.K. On Language and Linguistics, vol. 3. Londres: Continuum, 2003. 